\title{
Um autor em movimento: uma reflexão sobre o escritor brasileiro contemporâneo através da obra de João Gilberto Noll

\author{
Renata Fernandes Magdaleno ${ }^{1}$
}

O boom que atingiu a literatura latino-americana em meados do século XX é apontado como o momento de maior profissionalização do escritor da região, processo que começou no século XIX, com uma gradativa autonomia do autor latino-americano, mas que deu um pulo com a explosão do mercado editorial na década de 1960 . Foi o período em que a produção de muitos autores passou a circular além das fronteiras locais e em que alguns escritores puderam viver de seu próprio trabalho. Uma época áurea e que parecia única, um momento isolado na história da literatura da região.

Ángel Rama, na coletânea de artigos La novela en América Latina (1982), afirma, em artigo escrito na década de 1960, que, com raras exceções, o escritor da região nunca conseguiu viver de literatura e sempre precisou ter uma dupla jornada de trabalho. Rama acredita, inclusive, que o estilo corrido e cheio de arestas de quem escreve nos momentos vagos, depois de horas de trabalho remunerado, marca as produções locais.

Silviano Santiago, no texto "Vale o quanto pesa", de 1978, explica com números esse panorama. Tomando o escritor e o mercado brasileiros como exemplo, prova com números as dificuldades de se viver da escrita. A produção literária, em toda a era pré-internet, circulava basicamente em livros (Santiago descarta, nesse artigo, a importância da crônica, que era divulgada pelos jornais), com uma tiragem média de três mil exemplares por edição. Nos melhores casos, 12 a 15 mil cópias circulavam pelo país em 15 anos, atingindo, de forma otimista, de 50 a 60 mil leitores, em uma época em que havia 110 milhões de brasileiros. Santiago ainda leva em conta a concorrência que o autor nacional sempre sofreu em relação aos escritores estrangeiros e o perfil dos leitores. Segundo o crítico, o reduzido público leitor no país é sofisticado e sem tempo, habitante de metrópoles movimentadas, com vidas corridas para administrar. Um cenário difícil para quem pretende viver da escrita.

Uma análise superficial do mercado literário atual parece apontar uma melhora nesse panorama. Em entrevistas, alguns autores vêm afirmando

\footnotetext{
${ }^{1}$ Mestre e doutora em Estudos de Literatura pela Pontifícia Universidade Católica do Rio de Janeiro (PUC-Rio), Rio de Janeiro, Brasil. É coorganizadora do livro Nósotros: diálogos literários entre o Brasil e a América Hispânica. E-mail: renata.magdaleno@gmail.com
} 
que a globalização, com uma maior interação dos mercados, a explosão de eventos ligados à literatura e as novas tecnologias, que possibilitam uma publicação mais independente, vem fazendo do início do século XXI um outro momento em que escritores da região vêm conseguindo viver de sua escrita. Mónica Bernabé, no artigo "La cultura de las humanidades en los tiempos de la posmodernidad" (2010), explica a forma como o campo literário se desenvolveu e enumera novos meios, eventos e veículos surgidos nos últimos anos, que aumentam a exposição da figura do escritor e a consequente divulgação do seu trabalho.

Na verdade, o processo se acelerou sobretudo com a expansão da internet, provocando uma dispersão absoluta do campo da cultura e da literatura, agora propagado na academia, na web, nas revistas especializadas, nos comentários dos blogs, nos suplementos dos periódicos, nos congressos de literatura, nos prêmios que se promovem nas diferentes mídias, nos programas culturais de televisão, nas feiras de livro cada vez mais populares. Diria-se que a literatura não morreu, mas que se modificaram substancialmente as formas tradicionais de sua produção, circulação e consumo². (Bernabé, 2010, p. 160, tradução nossa)

Em Ficção brasileira contemporânea (2010), Karl Erik Schøllhammer, analisando o mercado nacional, afirma que a estabilização econômica do país possibilitou um aquecimento na venda de livros e a criação de uma série de feiras, encontros com os leitores e festas literárias. Seguindo o modelo bem-sucedido da Festa Literária Internacional de Paraty (Flip), que acontece desde 2003, surgiram a Festa Literária Internacional de Porto de Galinhas (Fliporto), de Passo Fundo, Porto Alegre, o Fórum das Letras de Ouro Preto, só para citar os principais exemplos brasileiros.

O modelo de sucesso da festa de Paraty criou outros filhotes pelo mundo. Na edição do dia 4 de agosto de 2010, o caderno cultural do jornal $O$ Globo publicou uma matéria intitulada: "De Paraty para o mundo". No texto, o repórter André Miranda defende que a Flip se transformou em um dos mais importantes eventos internacionais do mundo literário, inspirando outros festivais pelo mundo, como o Hay Festival Cartagena das Índias, na Colômbia, o Palfest, na Palestina, e com o projeto de ganhar

\footnotetext{
${ }^{2}$ No original: "De hecho, el proceso se aceleró notablemente con la expansión de Internet provocando una absoluta dispersión del campo de la cultura y de la literatura, ahora diseminados en la academia, la web, las revistas especializadas, los comentarios de los blogs, los suplementos de los periódicos, los congresos de literatura, los premios que promueven los multimedios, los programas de televisión cultural, las ferias del libro cada vez más populares. Se diría que la literatura no ha muerto sino que se han modificado sustancialmente las formas tradicionales de su producción, circulación y consumo".
} 
uma franquia inglesa. O sucesso é contabilizado pelo público que visita a cidade durante o evento. Em 2006, 12 mil pessoas visitaram a cidade e, em 2009 e 2010, o número subiu para 20 mil. Durante a festa, os escritores convidados recebem tratamento de celebridade, estampando a capa dos principais jornais do país.

O aquecimento do mercado literário não se restringe aos festivais. Em algumas cidades do país surgiram casas especializadas em cursos rápidos, onde escritores, críticos e intelectuais ministram aulas. O Plano Nacional do Livro e Leitura divulgou, só em 2008, mais de 200 atividades de promoção da leitura ${ }^{3}$ (Schøllhammer, 2009, p. 18). “Assim, a atenção em torno da pessoa do escritor cresceu, e a figura espetacular do 'autor' tanto quanto o objeto livro ganharam maior espaço na mídia” (id., p. 19).

Aumentam as possibilidades, mas também a exposição da figura do escritor e as demandas do mercado. Em Leitores, espectadores e internautas (2008), Canclini dedica um capítulo de seu livro ao que ele chama de a necessidade de provocar assombro, que teria como objetivo atrair o público. Para o autor, as artes de vanguarda trabalhavam com o assombro, mas numa época de mercado competitivo e fronteiras alargadas, as editoras criaram essa necessidade do assombro, de atrair a atenção do público para a obra, seja expondo o escritor em eventos ou prometendo divulgar estratégias de sua escrita. Expondo a figura do autor como aperitivo para a venda da sua obra. "No momento em que as artes deixaram de chamar-se de vanguarda, cederam ao mercado, às galerias, aos editores e à publicidade a tarefa de provocar assombro para atrair público" (id., p. 14).

A intenção desse artigo é pensar esse momento utilizando como lente a obra do escritor João Gilberto Noll, especificamente o romance Lorde (2004). A obra de Noll ficou atrelada à discussão de questões contemporâneas e, talvez por isso, seja tantas vezes analisada. Há inúmeras teses de doutorado, centenas de dissertações de mestrado, dezenas de capítulos de livros e um número incontável de artigos sobre o escritor. Características dos tempos atuais, como a falta de referência e de sentido, estão presentes no protagonista de seus romances, um andarilho-viajante vagando sem fim, que aparece livro após livro. Um personagem que caminha em um contexto de crise dos grandes relatos legitimadores, perda das certezas, descentramento do sujeito, deslocamento de um ponto de vista onisciente e totalizador para uma pluralidade de vozes, num tempo onde as certezas foram substituídas pelas opiniões e pontos de vista. Elementos dissecados por teóricos como, por exemplo, Lyotard, Fredric Jameson e Habermas,

${ }^{3}$ Mais números e informações em: <http://www.pnll.gov.br>. 
preocupados em definir as mudanças em uma época que foi caracterizada por muitos como pós-moderna.

Schøllhammer reforça a relação da obra de Noll com as teorias ligadas à pós-modernidade e a falta de sentido desse homem sem as amarras seguras que existiam na modernidade.

Noll cumpre uma trajetória que o identifica, inicialmente, como o intérprete mais original do sentido pós-moderno de perda de sentido e de referência. Sua narrativa se move sem um centro, não ancorada num narrador autoconsciente; seus personagens se encontram em processo de esvaziamento de projetos e de personalidade, em crise de identidade nacional, social e sexual, mas sempre à deriva e à procura de pequenas e perversas realizações do desejo. (Schøllhammer, 2009, p. 32)

No estudo Identidades em vôo cego (2004), Analice de Oliveira Martins reforça a ligação da obra do escritor com as alterações do mundo contemporâneo afirmando que:

A obra do gaúcho/carioca João Gilberto Noll ficcionaliza, de certa forma, uma trajetória das individualidades contemporâneas, assim como, promove, em alguns momentos, uma desreferencialização bastante radical do espaço geográfico, sem contudo apagar as marcas da condição urbana. Talvez mais do que qualquer outra em seu conjunto, a ficção de Noll traga à baila personagens em trânsito, deslocando-se não só por lugares e não-lugares como também por outras individualidades, outros "selfs". A condição de nomadismo aqui é recorrente. (Martins, 2004, p. 79)

A autora associa uma certa desreferencialização, um vagar sem sentido, com uma busca por pertencimento. A falta de bagagem que os personagens do escritor apresentam em muitos dos livros aparece como um indício da falta de raízes. É como se não tivessem passado, lar, história, para onde voltar. Vagam como estrangeiros destituídos de casa, que buscam em lembranças, no corpo de familiares e amantes a procura por esse pertencimento. Só nessas possessões seria possível encontrar algum pertencimento, mesmo que transitório. As histórias do autor estariam, então, segundo sua visão, de acordo com a discussão contemporânea da coexistência de múltilos pertencimentos.

Dois livros do autor inserem um personagem escritor, com as mesmas características de Noll, nesse contexto de falta de sentido e atmosfera onírica que já caracterizava a sua obra: Berkeley em Bellagio (2002) e Lorde. Por 
isso, é complicado analisar Lorde sem levar em conta Berkeley em Bellagio (2002), que guarda tantas semelhanças. Em Espectáculos de realidad (2007), Reinaldo Laddaga defende que um romance precisa necessariamente ser lido em parceria com o outro. "É preciso ler este livro (Lorde) junto com Berkeley em Bellagio, e os dois como dois atos de uma mesma comédia: a comédia da vida do escritor na época em que seus meios de subsistência proveem sobretudo de universidades e fundações" (Laddaga, 2007, p. 90, tradução nossa) $)^{4}$.

Berkeley em Bellagio fala de dois convites recebidos por Noll na vida real e vividos por seu personagem na ficção: no fim da década de 1990, o escritor é convidado a ensinar literatura na universidade da Califórnia e a passar um período numa residência para escritores mantida por uma instituição na cidade de Bellagio, na Itália. A temática do romance faz pensar nos compromissos cumpridos por escritores contemporâneos, que não apenas escrevem seus livros, mas vivem num emaranhado de demandas e deslocamentos que a profissão exige nos dias de hoje.

A mesma questão aparece claramente discutida nas páginas de Lorde. O escritor-personagem do romance foi convidado por um indivíduo inglês para uma espécie de missão em terra estrangeira. O objetivo da viagem permanece obscuro até o fim da história, mas, apesar das interrogações do personagem, percebemos logo de início que saber o motivo do convite não é algo que tenha realmente importância.

A pura verdade vinha de que eu não tivera escolha. Então eu vim. Parece fácil dizer "então eu vim" - alguém todo preparado para atravessar o Atlântico de uma hora para outra, sem ter nada o que deixar que carecesse da sua presença. (...) Poderia dizer que antes eu teria de resolver isso e aquilo. Não, que nada, eu teria apenas de trocar minha solidão de Porto Alegre pela de Londres. E ter na Inglaterra uma graninha extra para me sustentar. (Noll, 2004, p. 10)

O cenário que vai sendo desenhado é contraditório. Os convites para participar de encontros, palestras, os períodos como convidado em universidades estrangeiras sustentam esse escritor, possibilitam que viva da escrita, mas parece que continua a ser difícil se manter para os que não entram nessa rota de eventos e viagens. Pelo menos, essa é a visão que aparece em Lorde.

\footnotetext{
${ }^{4}$ No original: "Hay que leer este libro (Lorde) junto con Berkeley en Bellagio, y a los dos como dos actos de una misma comedia: la comedia de la vida del escritor en la época en que sus medios de subsistência provienen sobre todo de universidades y de fundaciones”.
} 
O escritor da história parece cansado dessa rotina. Envolto em uma crise criativa, sem vontade de escrever, o autor chega à Inglaterra disposto a criar uma nova vida, uma nova história, a deixar para trás de vez o passaporte brasileiro que traz guardado no bolso e arrumar um inglês que lhe possibilite um recomeço. Então, ele veio. E logo nas primeiras páginas caminha para essa transformação, com o intuito de deixar a antiga imagem e vida para trás e construir outra. O primeiro sintoma é que começa a se desconhecer, esquecer sua história, pensa que, se olhar seu rosto no espelho, talvez até encontre já outro em seu lugar. Ele quer deixar para trás uma vida de incertezas, de precariedades materiais. Para a imprensa, afirma orgulhoso que sua estadia em Londres será uma oportunidade de representar o Brasil no exterior, mas a verdade é que a graninha (e o diminutivo nesse caso é proposital, já que a todo momento o personagem reforça como é pequena a remuneração) garantirá sua subsistência nos meses seguintes.

$\mathrm{Eu}$, que tinha vivido aqueles anos, vamos dizer, nu no Brasil, sem amigos, vivendo aqui e ali dos meus livros, no menor intervalo a escrever mais, passando maus pedaços e todo cheio de piruetas para disfarçar minha precariedade material não sei exatamente para quem, pois quase não via ninguém em Porto Alegre. Sim, disfarçara em entrevistas ao lançar meu derradeiro livro, sim, vou passar uma temporada em Londres, representarei o Brasil, darei o melhor de mim - o quá-quá-quá surfava na minha traquéia sem poder sair, entende? (id., p. 11)

Estamos diante, logo nas primeiras páginas, do encontro de um inglês e um brasileiro. Este último chegou convidado pelo primeiro, financiado, mas sua atitude e situação é de dependência e submissão. Ele não teve escolha. Ele precisa dos magros subsídios que a suposta universidade europeia fornece para a sua modesta subsistência, e tudo que for preciso fazer para que o pagamento não falte, será feito, até reunir montes de notas fiscais que comprovem cada centavo gasto, cada item comprado, bolos de notas que ele vai acumulando no bolso e estende para o inglês toda vez que parece necessário, em troca do dinheiro para a subsistência.

Um inglês e um brasileiro. Existem diferenças marcadas na simples citação das nacionalidades. A relação não é igualitária. Em $O$ cosmopolitismo do pobre (2004), Silviano Santiago fala de um novo tipo de cosmopolitismo, surgido graças aos desenvolvimentos tecnológicos. A democratização dos meios de transporte e de comunicação alargaram as fronteiras da população que antes, por falta de recursos, não participava dos acontecimentos globais. Os desfavorecidos do mundo, em busca de melhores condições de vida, pas- 
saram a migrar não para os grandes centros urbanos de seus países, mas para as grandes metrópoles do mundo, muitas vezes, de forma ilegal.

Os desempregados do mundo se unem em Paris, Londres, Roma, Nova Iorque e São Paulo (...) Hoje os retirantes brasileiros, muitos deles oriundos de estados relativamente ricos da nação, seguem o fluxo do capital transnacional como um girassol. Ainda jovens e fortes, querem ganhar as metrópoles do mundo pós-industrial. (Santiago, 2004, p. 52)

Para Santiago, uma vez estabelecidos no novo país, esses imigrantes passariam a ser tolerados como mão de obra barata, capaz de executar serviços necessários para o bom funcionamento da sociedade, mas que os habitantes locais não estão dispostos a se submeter.

O fluxo dos seus novos habitantes é determinado em grande parte pela necessidade de recrutar os desprivilegiados do mundo que estejam dispostos a fazer os chamados serviços do lar e de limpeza e aceitem transgredir as leis nacionais estabelecidas pelos serviços de migração. São predeterminados pela necessidade e pelo lucro pós-moderno. (id., p. 51)

Ao falar dessa população de imigrantes, Santiago se refere principalmente àqueles que estão à margem, longe dos grandes centros econômicos mundiais. Esse movimento resultaria, à primeira vista, em um multiculturalismo, mas esconderia uma espécie de etnocentrismo disfarçado, que toleraria o imigrante, o outro, para que este ocupe setores desvalorizados e subempregos nas metrópoles. Esse outro pode se instalar, mas só até determinado ponto, pode chegar apenas até determinados setores da sociedade, determinados empregos, morar apenas em determinados bairros. E sua situação ilegal aparece no fundo como uma vantagem, já que favorece a atitude de submissão.

Instalados nesse novo país, estes imigrantes se reúnem em comunidades de indivíduos agrupados por afinidades culturais. No estrangeiro, criam grupos que reforçam ainda mais sua condição de estranhos naquele ambiente, se transformam em minorias, vivendo em bairros de imigrantes, falando seu idioma natal entre si etc.

O escritor do romance, apesar de ter sido convidado por uma universidade inglesa, de certa forma se identifica com essa realidade. Foi para a Inglaterra em busca da bolsa, que, apesar de ser descrita como irrisória, o possibilitaria viver nos próximos meses. E quer se instalar lá, como se a antiga casa representasse um período difícil que ele pretende esquecer. Logo que pisou em solo estrangeiro, o homem que o convidou 
foi ao aeroporto buscá-lo e, sem mais explicações, o deixou por horas esperando em uma sala de escritório, enquanto terminava seus afazeres diários para, depois, o levar para o bairro de Hackney, onde ficaria hospedado. "Um bairro que eu sabia longíquo, ao norte de Londres, de imigrantes vietnamitas, turcos, já fora das margens dos mapas da cidade que costumam propagar em folders turísticos" (Noll, 2004, p. 15). Mesmo convidado, ele reforça que continua à margem. Noll exagera ao incluir seu escritor em um bairro de imigrantes, onde estão os excluídos daquele país, ao reforçar que ele prefere ter que se submeter ao que for preciso do que voltar para casa, para seu país, relacionado no livro sempre a uma ideia de solidão e penúria. Teoricamente, existe uma distância muito grande entre os imigrantes citados por Silviano Santiago em seu texto e um escritor convidado para passar um período como convidado em uma universidade de Londres. Mas Noll aproxima essas duas figuras, reforçando que, pelo menos para ele, a dependência, a submissão e a falta de reconhecimento permanecem.

Permanece a ideia de alguém que vem da margem e, em Londres, continua nela, em um bairro distante, já fora dos limites da cidade, habitado por imigrantes.

O meu apartamento ficava em cima de um restaurante vietnamita, de esquina, justamente do dono que o alugaria em nome do inglês ou de sua instituição. (...) Andávamos pela noite da Mare Street no bairro de Hackney com muito vento, frio, passando por sua população de africanos, caribenhos, vietnamitas, turcos; queria me mostrar o Victoria Park, que ele mesmo não conhecia. (id., p. 18-9)

O lugar onde fica hospedado é desconhecido do próprio inglês, que precisa consultar mapas, se perde nas ruas em busca dos pontos que quer apresentar ao seu hóspede. A situação é de aceitação, submissão, e, em alguns momentos, humilhação.

Por outro lado, há também outro tipo de herança histórica com a qual esse personagem-escritor precisa lidar: a visão que fazem de um autor brasileiro em terras estrangeiras. No artigo "Identidades e nomadismos" (1999), Zilá Bernd defende que as viagens que marcaram a história do continente latino-americano desenvolveram uma espécie de discurso que fez com que o habitante local se visse pela falta, focando em tudo aquilo que faltava para chegar à semelhança do dominador. Ao mesmo tempo, o colonizador, ao ver os latino-americanos por analogia, seguiria o mesmo movimento. Uma visão e um discurso binários que, segundo a autora, deixaram resquícios até os dias de hoje. 
Esta visão etnocêntrica, que dividia o mundo entre civilizados e bárbaros e que se recusava a reconhecer os ameríndios em sua alteridade, terá tendência a cristalizar-se como doxa até nossos dias, gerando o preconceito e o racismo. Ao invés de ir gradativamente se atenuando, esta ideologia foi sendo reforçada de diferentes modos. (Bernd, 1999, p. 97)

Em seu texto, Bernd segue refletindo sobre a busca por uma identidade que combinasse com a trajetória do continente. Mas interessa pensar em como Lorde reforça a presença desses resquícios. Apesar de estar em um mundo globalizado, com facilidades de locomoção, com convites que o possibilitem ir e vir cruzando fronteiras, o personagem-autor da trama de Noll não é tratado de forma igualitária, ainda é visto como alguém que vem da margem e precisa se submeter a uma renda pequena, a uma moradia num subúrbio afastado e de imigrantes, alguém, também, que vem de uma cultura "exótica" e talvez possa dar um depoimento encharcado de uma autenticidade e de uma lealdade desconhecidas e almejadas. Ao pensar nas intenções do inglês, o protagonista afirma:

Por mim morreria para as próximas horas, sem querer saber da legitimidade de propósitos daquele inglês que me chamara de um país longínquo e que parecia querer tirar de mim uma fonte de genuína presença - assim como se eu ser eu, pronto, vindo da autenticidade de uma terra ao sul, pudesse conferir aos britânicos uma lealdade sem par, ainda inédita entre outros povos. (Noll, 2004, p. 22-3)

Silviano termina seu texto pensando em como esse deslocamento que atinge os desprovidos de renda pelo mundo, facilitado pelas novas tecnologias, pela economia globalizada, pelos meios de transporte, chegou também a outros setores da sociedade, como, por exemplo, o de intelectuais e artistas latino-americanos. Desde 1960, a fundação de órgãos de fomento à pesquisa tem possibilitado intercâmbios internacionais: jovens pesquisadores e professores cruzam fronteiras para aprimorar seus conhecimentos em universidades estrangeiras. E o movimento contrário também existe: pesquisadores e professores internacionais aportam em países latino-americanos para, teoricamente, transmitir seus conhecimentos. De uns anos para cá, o mesmo acontece com escritores, convidados a passar períodos em universidades estrangeiras, a participar de eventos internacionais, seminários, encontros com leitores ${ }^{5}$.

\footnotetext{
${ }^{5}$ A própria trajetória de Noll serve como exemplo para comprovar uma afirmação como essa.
} 
Noll em seu romance faz uma ponte entre o deslocamento dos "pobres" e dos intelectuais, tão diferente em tantos pontos. O que ele parece querer mostrar é que há uma herança com a qual esse escritor precisa lidar.

Noll com sua história traça um panorama não muito otimista. Segundo seu personagem viajante, é possível viver da escrita se submetendo ao fluxo do mercado, mas é preciso pagar um preço caro pela realização profissional. Apesar dos sete livros publicados, do sucesso literário que o faz receber convites internacionais, ele não consegue atingir autonomia, precisa representar os papéis que lhe forem impostos.

cheguei à nítida conclusão de que a vida não me queria em perfeitas condições, é isso. Deu-me sete livros, é verdade. Mas, apesar deles, onde eu encontrava a minha autonomia? Até quando escravo de uma maquinação secreta sem vislumbre de alforria? Já falei, ser escravo não é nada, mas que se saiba realmente de quem ou do quê. (id., p. 68)

Para levar a situação de falta de autonomia ao extremo, o escritor se vê envolvido em uma operação militar. Vê o inglês de uniforme entrar em um veículo militar e se sente uma espécie de prisioneiro, parte de alguma operação sigilosa. Sofre desmaios, se vê internado num hospital e volta ao seu apartamento com a sensação de que realizaram nele algum tipo de teste. Teria sofrido alguma metamorfose dentro do hospital? Teria se transformado em outro, enquanto o escritor antigo continuava preso em algum quarto daquele mesmo hospital ou morrido talvez?

Além da sua vontade de ser outro para se instalar no novo país, existe um outro que é a imagem que o público e os leitores que ele encontra pelo caminho fazem dele. Ao falarem de seus escritos, por exemplo, a interpretação sempre parece algo que ele não consegue entender, mas que aceita como se o que pensam de sua obra fosse algo sem importância, o mais essencial é receber financiamento para sobreviver. No primeiro encontro que teve com o inglês, ainda no Brasil, este lhe pediu os seus exemplares

porque não os encontrara nas livrarias por onde tinha andado à tarde e no dia seguinte retornaria para a Inglaterra. Que precisava conhecer no meu trabalho aquilo que chamavam de algo que não entendi e que lhe vinha interessando muito nos últimos anos, ah, e sobre o qual vinha escrevendo um livro. Se não me engano esse livro falava de alienígenas. Era isso? (id., p. 11)

Ao apresentar o bairro onde ficaria hospedado, o inglês fala de como ele pode continuar com sua rotina no novo ambiente. 
Eu poderia fazer as minhas caminhadas matutinas. Aquelas que eu costumava fazer todas as manhã à beira do Guaíba, entre a Usina do Gasômetro e o teatro Pôr-do-Sol. Ele sabia, não lembrava se eu mesmo lhe contara. Ele sabia..., repeti em silêncio. Ele sabia o que eu mesmo já não sabia mais. Tudo o que vivera até ali parecia estar indo embora. (id., p. 19)

O inglês faz uma imagem dele como autor e pessoa que ele mesmo não se reconhece ou talvez tenha esquecido, como afirma. A imagem é apresentada com tanta convicção que acredita que talvez o inglês saiba mais do que ele de sua rotina e de seus escritos. De qualquer forma, ao recordar de suas observações sobre seus livros, pensa em alienígenas. Tudo parece estranho. Ele é a marionete, que precisa se adaptar à nova condição.

Quando se imagina na apresentação que talvez tenha que fazer para um público de leitores e estudiosos, compara a sua fala a uma performance. Primeiramente, a situação lhe parece semelhante a uma tortura. Depois, conforme vai seguindo, se vê em uma performance tantas vezes repetida. Um personagem atuando para atender à demanda da massa, limpando a maquiagem que escorre do rosto, tentando extrair histórias de sua vida, reais ou não, o que importa é provocar o riso, agradar à plateia, atender bem à demanda, proporcionar o show esperado pela audiência.

Ele queria que eu falasse do Brasil para uma audiência de seiscentas pessoas? Ah, me vinha logo um lago e eu entrando nele devagar, bem devagar porque a água estava fria e eu não tinha ainda carne suficiente para suportar. Minha pele, couro de arreio. Eu olhava em volta e não via ninguém (...) Mais?, aguentar mais um pouco o ferrão do gelo em que eu tinha me metido e então me afogar. (...) eu retiraria das entranhas essas e outras imagens, vividas ou não (...), com a dificuldade exposta, valendo pontos - delas extrair... (...) Tinha dito coisas para o público que talvez eu repetisse em todas as minhas palestras, talvez tudo não passasse de uma simples repetição à qual as pessoas costumavam aderir com certa veemência por eu saber aturdi-las com minha retórica poética. (id., p. 30-1)

É como se sua atuação valesse pontos, por isso, enquanto fala, observa o comportamento do inglês e espera seu olhar de aprovação. Na verdade, vale ponto, vale a remuneração que recebe ao fim do mês. Tudo para esse personagem parece ser melhor do que ter de voltar para casa.

Em Londres eu morreria satisfeito, juro. O que não podia era dar meia-volta e retornar ao Brasil. Para que isso não acontecesse seria capaz de matar. Eu estava despindo minha covardia, juro. As mãos 
vagas, à espera da arma. Estava cagando para as consequências. $\mathrm{Ou}$ acham que um homem não pode deixar de ser covarde assim, de estalo... Não é de estalo, cara: é que ficar como ficou, de um lado, ou voltar para a América do Sul no horizonte, de outro, faz com que eu não me reconheça mais, me transfigure, saia desse meu corpinho idiota aqui, me vomite de asco, vire outro. (id., p. 81-2)

Desde que desembarca do avião, está disposto a ser outro, a ser aquilo que queiram que ele seja. E a metamorfose se insinua já nas primeiras páginas do romance, quando compra um estojo de maquiagem e passa no rosto tentando esconder as antigas marcas, uma maquiagem que escorre enquanto caminha pela cidade, revelando aquilo que tenta tanto esconder. Ou quando vai a um salão de cabeleireiro e pinta os cabelos num tom novo. Esse outro aparece como uma espécie de adequação entre a imagem que fazem dele e o seu desejo de começar uma nova vida, sem tantas incertezas financeiras. Está disposto a se adequar a esta imagem para atingir o seu objetivo. Ele se sente "parte daqueles autores imigrantes, sem nacionalidade precisa, sem bandeira para desfraldar a cada palestra, conferência" (id., p. 33).

Seguindo o raciocínio de Julia Kristeva, em Estrangeiros para nós mesmos (1994), as transformações sofridas no corpo estariam associadas à própria condição de estrangeiro e à natureza da viagem.

Sem dúvida, é a explosão do recalcamento que conduz o estrangeiro à travessia de uma fronteira rumo ao exterior. Separar-se da sua família, do seu idioma, do seu país, para vir se assentar em outro lugar é uma audácia acompanhada de um frenesi sexual: sem mais proibições, tudo é possível. Pouco importa se a passagem da fronteira é seguida por uma orgia ou, pelo contrário, por um recolhimento medroso. O exílio sempre implica uma explosão do antigo corpo. (Kristeva, 1994, p. 37)

Como em outros tantos livros do autor, estão presentes também em Lorde a atmosfera onírica, o personagem que segue um fluxo sem vontade própria, o corpo posto a prova, sofrendo as consequências. Na história de Noll, as transformações físicas a que se submete o personagem (a maquiagem, a tintura...) ou que imagina (a troca de personalidade no hospital, a vontade de fugir de espelhos para deixar de comprovar se o reflexo que aparece é de outra pessoa...) estão associadas a um frenesi sexual. Um corpo que funciona sexualmente, apesar de parecer doente e sem forças. Homens que cruzam o seu caminho e despertam desejos sexuais nunca concretizados. Pessoas que ele vê ou conhece e que aparecem como a pos- 
sibilidade de uma noite de sexo e, junto com isso, a chance de um recomeço, uma nova vida. Se concretizasse suas aspirações, ele não teria apenas o inglês a quem se apoiar, mas também esse outro ser, que o possibilitaria assumir outra identidade e não voltar mais para o Brasil.

O sexo, de certa forma, também aparece associado à geração de uma nova vida, mas, no caso, uma nova vida para ele mesmo. A possibilidade de ser outro através do sexo. E é justamente isso o que ocorre ao fim do livro. Noll-personagem se vê sozinho, sem apoio (o inglês acabara de se suicidar pulando de uma ponte) e, depois de perambular por horas sem saber o que fazer, se dirige a uma estação de trem, rouba de um passante uma carteira recheada de libras e compra uma passagem para Liverpool. Lá, na nova cidade, uma professora o vê passar pela rua, o reconhece como o autor que ela tanto admira, o procura no hotel e lhe faz uma proposta para dar aulas de português na universidade local. Estão justamente precisando de um professor de português, e ele aceita o convite, vai assumir o cargo. Finalmente, tem emprego, salário garantido, vai poder ficar, não precisará mais voltar ao Brasil. Mas a história não para por aí.

Ele decide comemorar o golpe de sorte em um bar. Lá conhece um antigo trabalhador da estiva, dono de uma loja de ferragens, com um sol cheio de raios tatuado em um dos braços. O encontro sexual, tantas vezes ensaiado ao longo da história e nunca realizado, enfim, acontece e, com este, se concretiza a mutação.

A primeira coisa que vi foi o sol rodeado de raios tatuado no meu braço. Abaixei a cabeça para não surpreender o resto. Murmurei: Mas era no meu braço esse sol ou no de George? O espelho confirmava, não adiantava adiar as coisas com indagações. Tudo já fora respondido. Eu não era quem eu pensava. Em consequência, George não tinha fugido, estava aqui. Pois é, no espelho apenas um: ele. Alguém escapara pela porta do quarto? Mantive-a aberta, precisava pensar... Resistia ainda qualquer excrescência de minha figura para poder ter ido embora? Ah, não: fechei a porta, passei a chave. (Noll, 2004, p. 109)

Ele não foi embora, se deixou transformar, virou outro. Um corpo que respondeu aos seus anseios, que concretizou na carne o desejo de mudança e fuga da trajetória instável que levava. Mas, ao mesmo tempo, é também de certa forma uma concretização da falta de autonomia. Se deixa incorporar, virar aquilo que queiram ou que preciso for.

Entre as primeiras páginas de Espectáculos de realidad (2007), Reinaldo Laddaga recorre a uma das cenas do livro Berkeley em Bellagio (2003), de Noll: o personagem-escritor se vê exposto, em algum museu, como uma 
peça para a apreciação do público, sem vontade própria ou autonomia, a mercê daquele que ganhará dinheiro com a mostra da figura do escritor. Nas catacumbas eu me rendo, não sei exatamente a que ou a quem, me rendo, sei que não quero nem saber se fui idealizado por alguém; se esse alguém existe que me exponha para ganhar a sua grana num museu em Nova Iorque, em São Francisco, Chicago (...) eu ficarei aqui à espera que encontrem o meu museu e nele eu possa produzir riquezas só com a minha auto-exposição: eu ali parado no retângulo envidraçado, correntes forradas de veludo em volta para que não se aproximem tanto, quem sou? por que provoco tamanha curiosidade alheia?, o que faço?, se é isso que todos querem ver, enfim, eu sou alguém que nada faz, que nada tem, nem ao menos o seu próprio corpo ${ }^{6}$. (Noll, 2003, p. 51-2)

A cena, de certa forma, sintetiza uma ideia presente no romance: a de uma escrita que não basta mais para a sobrevivência desse escritor. A ficção precisa transbordar as páginas de seus livros. É preciso realizar performances. Laddaga afirma:

É impossível não identificar esta criatura com João Gilberto Noll, escritor em crise de sobrevivência, e ao livro como um minúsculo mapa dos circuitos que sustentam o trabalho de um número considerável de escritores mais ambiciosos da região em condições contemporâneas. O livro é uma breve fantasmagoria e uma meditação ${ }^{7}$. (Laddaga, 2007, p. 12)

\footnotetext{
${ }^{6}$ A cena descrita por Noll foi, de certa forma, vivenciada tempos depois pela escritora Paula Parisot. Em março de 2010, durante o lançamento do seu romances Gonzos e parafusos, a autora ficou confinada por sete dias em uma caixa de acrílico de três por quatro metros em uma livraria de São Paulo, seguindo os passos da protagonista de sua história, uma psicanalista que decide se internar para se livrar do passado. A performance contou até com a participação do escritor Rubem Fonseca, que foi ao local alimentar a autora. Centenas de pessoas foram à livraria especialmente para observar a reclusão de Paula. A autora prometeu ainda realizar outra performance semelhante durante o lançamento do livro em Portugal e lançar, no fim do mesmo ano, um livro com os escritos e desenhos realizados durante o período de confinamento. Ao falar sobre o feito para o blog do caderno literário do jornal $O$ Globo, Prosa \& Verso, a escritora afirmou: "Jamais, em nenhum momento, pensei em fazer a performance para vender mais livros. Uma performance não é uma forma de propaganda, é uma forma de expressão. Eu propus uma forma diferente de contato entre o leitor e o autor. É comum artistas plásticos ou músicos fazerem performances e isso não significa que eles estejam querendo vender mais quadros, esculturas ou CDs" (Parisot, 2010).

${ }^{7}$ No original: "Es imposible no identificar a esta criatura con João Gilberto Noll, escritor en trance de sobrevivencia, y al libro como un minúsculo mapa de los circuitos que sostienen el trabajo de un considerable número de escritores más ambiciosos de la región en condiciones contemporáneas. El libro es una breve fantasmagoria y una meditación".
} 
O livro aparece também como uma meditação sobre o lugar do escritor nesse mundo globalizado, sobre o ir e vir inevitável dos autores brasileiros contemporâneos que almejam viver da escrita. Em Lorde, Nollpersonagem tem outro destino, mas há cenas que levam à mesma reflexão, como a do personagem se exibindo para uma plateia de 600 pessoas. A escrita associada a uma ideia de performance.

Os dois livros ainda utilizam propositalmente elementos da vida do escritor misturados à ficção. Como se a própria trajetória de Noll reforçasse a ideia de submissão a um sistema. Noll nasceu em 1946 e sua trajetória literária é marcada por períodos passados em universidades estrangeiras. Em 1982, ganhou uma bolsa do programa de escritores da Universidade de Yowa, nos Estados Unidos. Entre 1996 e 1998 passou um período em Berkeley, nos Estados Unidos, convidado para lecionar cursos de literatura brasileira contemporânea na universidade. Depois, passou um mês como convidado na residência de escritores em Bellagio, na Itália. Em 2004, passou dois meses em Londres, como escritor residente no King's College, onde escreveu o romance Lorde (2004). Em outubro de 2009 viajou à Espanha e à Inglaterra, onde participou de palestras em Madri, Barcelona, Salamanca e Santiago de Compostela. Nos eventos, foram estudadas ainda as traduções para o inglês e espanhol da obra de Noll. O autor ainda escreve para jornais, participa de programas televisivos, esteve na Festa Literária de Paraty (Flip) de 2008, assim como em uma série de outros eventos literários. Inúmeras entrevistas com o autor já foram exibidas e publicadas em programas de televisão, sites, jornais, revistas...

Em O lugar do escritor (2003), livro em que o fotógrafo Eder Chiodetto capta o lugar de trabalho de 36 escritores brasileiros consagrados, João Gilberto Noll dá um depoimento de como, de certa forma, sua vida acabou por influenciar a sua escrita. E, que, por ter optado por se transformar em um escritor profissional, teve que se submeter a uma espécie de vida nômade, que acaba refletida nos personagens (ou no personagem, já que as características deste sempre se repetem, livro após livro) que escreve.

Toda a minha desenraização tem só um quê de romântico, nada mais do que um simples quê. $\mathrm{O}$ fato de ter vivido num hotel e de escrever à mão, tudo isso que poderia à primeira vista parecer glamour, não o é, de fato, mas sim dados de uma condição que vinha de uma opção insana que fiz há uns quinze, vinte anos pela literatura - no sentido de ser um escritor full-time, o que me fez viver algum tempo sob tetos alheios, escrever meus livros na casa de veraneio de um irmão em pleno inverno, para poder manter um espaço só meu para criar. Nesse panorama, custei um tanto para me sentir seguro geograficamente para poder conservar comigo uma 
máquina da estatura de um computador, sem ter de carregá-lo pelas estradas da vida como um saltimbanco ou sem-teto, que de fato fui ${ }^{8}$. (Noll, 2003)

Pelas lentes de Noll vemos escritores que ainda parecem buscar um lugar, num mundo dominado pelas leis de mercado, em que é preciso criar personagens, mitos, outros para atender às diferentes demandas de forma satisfatória. O escritor é associado a um produto, que aparece exposto em um cubo de vidro, para observação e visitação pública.

\section{Referências bibliográficas}

BERND, Zilo (1999). “Identidades e nomadismos". In: JOBIN, José Luiz (Org.). Literatura e identidades. Rio de Janeiro: Editora da Uerj. v. 1, p. 95-111.

CANCLINI, Nestor García (2008). Latino-americanos à procura de um lugar neste século. Iluminuras: São Paulo. CHIODETTO, Eder (2003). O lugar do escritor. São Paulo: Cosac Naif. FIGUEIREDO, Vera Lúcia Follain (s.d.p.). "Ficção e desenraizamento". In: Fórum Virtual de Literatura e Teatro. Disponível em: <http://www.pacc.ufrj.br/literatura/arquivo/polemica_ficcao_e_desenraizamento.php> . Acesso em: 13 dez. 2010. GOMES, Renato Cordeiro (2004). “Deslocamento e distância: viagens e fronteiras na cultura latino-americana: dramatização de marcas identirárias". In: JUNIOR, Benjamin Abdala; SCARPELLII, Marli Fantini. Portos flutuantes: trânsitos ibero-afro-americanos. São Paulo: Ateliê.

KRISTEVA, Julia (1994). Estrangeiros para nós mesmos. Rio de Janeiro: Rocco.

LADDAGA, Reinaldo (2007). Espetáculos de realidad: ensayo sobre la narrativa latinoamericana de las últimas dos décadas. Rosário: Beatriz Viterbo Editora. MARTINS, Analice de Oliveira (2004). Identidades em vôo cego: estratégias de pertencimento na prosa contemporânea brasileira. Rio de Janeiro: PUC-Rio.

NOLL, João Gilberto (2002). Berkeley em Bellagio. Rio de Janeiro: Objetiva. (2004). Lorde. São Paulo: Francis.

(2003). "O avesso do conhecimento". In: CHIODETTO, Eder. O lugar do escritor. São Paulo: Cosac Naify.

PARISOT, Paula (2010). "Paula Parisot fala sobre performance e sua relação com Rubem Fonseca". O Globo. Prosa \& Verso. 22 mar. Disponível em: <http://oglobo.globo.com/blogs/prosa/posts/2010/03/21/paula-parisotfala-sobre-performance-sua-relacao-com-rubem-fonseca-276499.asp $>$. Acesso em: set. 2010.

RAMA, Angel (1985). La critica de la cultura en America Latina. Caracas: Biblioteca Ayacucho.

\footnotetext{
${ }^{8} \mathrm{O}$ livro está indisponível para venda, mas o depoimento de Noll pode ser consultado no site dedicado a ele, disponível em: <http://www.joaogilbertonoll.com.br/depoimentos.html>. Acesso em: ago. 2010.
} 
(2008). Literatura, cultura e sociedade na América Latina. Belo Horizonte:

Editora UFMG.

(1985). A cidade das letras. São Paulo: Brasiliense.

SANTIAGO, Silviano (1971). Uma literatura nos trópicos. Rio de Janeiro: Rocco. PUC-Rio. (1982). Vale quanto pesa: a ficção brasileira modernista. Rio de Janeiro:

(2005). O cosmopolitismo do pobre. Belo Horizonte: Editora UFMG.

SCHOLLHAMMER, Karl Erik (2009). Ficção brasileira contemporânea. Rio de Janeiro: Civilização Brasileira.

Recebido em agosto de 2011.

Aprovado em outubro de 2011.

\section{resumolabstract}

Um autor em movimento: uma reflexão sobre o escritor brasileiro contemporâneo através da obra de João Gilberto Noll

Renata Fernandes Magdaleno

A globalização, o aumento de eventos literários, a presença da internet possibilitando novos meios de divulgação da obra. Fatores como estes vêm mudando a rotina de escritores e, por isso, o século XXI vem sendo apontado como um melhor momento para quem pensa em viver da escrita na América Latina. A figura do autor ganhou destaque. A intenção deste artigo é pensar esse momento utilizando como lente a obra do escritor João Gilberto Noll, principalmente o romance Lorde (2004).

Palavras-chave: escritor contemporâneo, Lorde, João Gilberto Noll

An author in movement: a reflection about the Brazilian contemporary writer through the work of João Gilberto Noll

Renata Fernandes Magdaleno

Globalization, more literary events, the internet providing an easier dissemination of the literary work. Factors such as these are changing the routine of brazilian writers. Because of that, the twenty-first century seems to be a better time for those who think to be a writer. The figure of the author gained prominence. The intention of this article is to think this moment using the work of João Gilberto Noll, especially the novel Lord (2004).

Key words: contemporary writer, Lord, João Gilberto Noll 